\title{
Translation and Paratexts: A Study of Animal Farm in Persian
}

\author{
Amin Amirdabbaghian ${ }^{1}$ and Shangeetha R.K. ${ }^{2}$ \\ ${ }^{1}$ Islamic Arts Museum Malaysia \\ Kuala Lumpur, Malaysia \\ ${ }^{2}$ University of Malaya \\ Kuala Lumpur, Malaysia
}

\begin{abstract}
Translators' ideology permeates all non-technical translations, and the need to study the extent to which ideology plays a vital role in the manipulation of literary texts with a political edge is undoubtedly important. As of Iran, the state ideology has been changed from secular to religious (Islamic) after the 1979 Islamic Revolution. This shift of ideology has influenced society in many facets, including language use. Therefore, individuals were encouraged to produce religious discourse to appear popular and this encouragement includes translation too (Amirdabbaghian 2019). This study aims to describe the ideological impact of the social situation (Islamic Revolution) in Iran on the translation of George Orwell's well-known political novel, Animal Farm (1945) into the Persian language. The research will apply van Dijk's (1998) theory of ideology and Lefevere's (1992) theory of translation, rewriting and manipulation of literary fame, to discuss the paratextual differences in both the source and target texts. The target text which has been chosen for the current research is Hosseini and Nabi Zadeh's (2003) version published by the Doostan publication in Tehran, Iran. Using the paratext of Animal Farm translated into Persian, this article makes an effort to prove that the translators' ideology influenced by their life experience, social status, and occupation as well as the situation and environment in the target language country may be revealed in the set of tactics used in translating the literary work, in the use of language and in the interpretation of the source text author's ideas expressed in the text.
\end{abstract}

Keywords: paratext, translation, Ideology, Persian, Animal Farm

\section{For Citation:}

Amirdabbaghian, Amin and Shangeetha, R.K. 2020. Translation and paratexts: A study of Animal Farm in Persian. Russian Journal of Linguistics 24 (1). 80-95. DOI: 10.22363/26870088-2020-24-1-80-95. 
Научная статья

\title{
Перевод и паратексты: \\ на материале перевода повести-притчи Animal Farm на персидский язык
}

\author{
Амин Амирдаббагхьян ${ }^{1}$, Шангита P.К. ${ }^{2}$ \\ ${ }^{1}$ Малазийский музей исламского искусства \\ Куала-Лумпур, Малайзия \\ 2 Университет Малайя \\ Куала-Лумпур, Малайзия
}

\begin{abstract}
Аннотация
Идеологические взгляды переводчика оказывают на все виды перевода, кроме технического. В связи с этим необходимо исследовать воздействие идеологии на манипуляции, которым подвергаются в процессе перевода литературные тексты с острой политической направленностью. После Исламской революции 1979 года иранская государственная идеология сменилась со светской на религиозную (исламскую), что оказало воздействие на разные стороны общественной жизни, включая использование языка. Применение религиозного дискурса стало средством повышения популярности индивидуума, что также сказалось на переводах. Цель настоящего исследования - описать идеологическое влияние социальной ситуации (Исламской революции) в Иране на перевод знаменитой повести-притчи Дж. Оруелла Animal Farm («Скотный двор») (1945) на персидский язык. Исследование опирается на теорию идеологии Т.А. ван Дейка (van Dijk 1998) и теорию перевода, переложения и манипуляции литературной славой А.А. Лефевра (Lefevere 1992). Оно направлено на обсуждение паратекстуальных различий в исходном тексте и переводе. В качестве материала настоящего исследования выступает перевод паратекста произведения Animal Farm (пер. Hosseini, Nabi Zadeh 2003), опубликованный издательством "Doostan" в Тегеране (Иран). В статье сделана попытка доказать, что идеологическая позиция переводчиков, сформированная под влиянием жизненного опыта, социального статуса и профессиональной деятельности, а также ситуация и окружение в стране, для которой предназначен перевод, может быть выявлена с помощью анализа тактик, используемых в процессе перевода литературного произведения, языка и интерпретации содержащихся в тексте идей автора.
\end{abstract}

Ключевые слова: паратекст, перевод, идеология, персидский язык, Animal Farm («Скотный двор»).

\section{Для цитирования:}

Amirdabbaghian, Amin and Shangeetha, R.K. 2020. Translation and paratexts: A study of Animal Farm in Persian. Russian Journal of Linguistics 24 (1). 80-95. DOI: 10.22363/26870088-2020-24-1-80-95.

\section{Introduction}

Translators frequently influence the evolution of the poetics of their time by means of their translations. Lefevere (1992: 25) believes that every translator is a prophet in his/her own language community and confirms it with a verse from the Quran where it is stated: 
We sent not an apostle except [to teach] in the language of his [own] people, in order to make [things] clear to them (The Quran 14: 4; translated by Yusuf Ali 2001).

Ideology and its impact on translation is a growing area of interest in the field of Translation Studies. The translators' personal ideology and the dominant social ideology of their environment can have a major influence on the final work. The translators can also be subjected to patronage, politics, and economic instigations or even limitations which can all affect their translations. André Lefevere (1992: 14) states that "ideology is often imposed by the patrons, the people or institutions who command or publish translations".

Animal Farm (1945) is one of the most popular works written by George Orwell and reveals his political viewpoints. The novel has been translated into Persian several times. There are plenty of studies investigating the ideological errors of Persian translations of this novel (Amirdabbaghian \& Solimany 2013; Khorsand \& Salmani 2014; Zareh-Behtash \& Chalabi 2016; Faghih \& Moghiti 2017). Almost all of those studies dealt with the errors only at a textual level. The present research, however, will explore the ideological issues in the Persian translation of Animal Farm (1945-2003) at a paratextual level. This highlights the fact that there is a scarcity of studies on the ideological impact of English novels translated into Persian.

\section{Power, Ideology, and Translation}

Ideology is a systemic body of concepts particularly concerning human life or culture and can be defined as a way and/or the content of thought characteristic of an individual, group, or culture, or a cohesive contention, theories and purposes that establish a socio-political program.

Van Dijk (1998) believes in a positive interpretation of ideology, but at present ideology has become an unclear concept, mainly referring to the politics and beliefs of a specific group of people. Van Dijk believes that Marxist and non-Marxist schools of thought are influencing factors in politicizing the approaches towards ideology.

On the other hand, Fairclough (1992: 90) believes that ideologies are naturalized and automatized conventions, and people may not recognize the influence of ideologies on their personality since "it is something inherited in the unconscious part of one's personality, so person reacts to responses in an automated way".

Based on the definitions above, it can be concluded that ideology is a systemic and organized set of opinions or concepts which are based upon individuals' social lives and cultures. In other words, it is a way of thinking that is distinguished between different social groups.

Ideology has been an important and increasing concern for translation scholars in recent decades. Hatim and Mason (1997: 161) state that "behind the systemic linguistic choices" made by a translator, there is "inevitably a prior classification of 
reality in ideological terms". This means that ideology affects languages at both lexical-semantic and syntactic levels. In other words, the ideology of a translator influences both lexical choices and grammatical structures. Hatim and Mason also believe that certain strategies applied in certain social and cultural circumstances to have ideological implications. Hatim and Mason (1997: 121) perceive the translator as a part of the social context and state: "it is in this sense that translating is, in itself, an ideological activity".

Lefevere (the 1980s to early 1990s) explains translation with relation to ideology and explores it as a kind of rewriting with essential manipulation depending on the professionals in the system, together with publishers, editors, revisers and the translators themselves; the patronage of literary systems among powerful institutions as well as individuals, which comprises ideological, economic and also critical elements which tend to limit translators' poetological space; and the dominant poetics, frequently appointed by the professionals, who can dictate which works are to be translated and the style adopted (Lefevere 1985 and 1992; Bassnett and Lefevere 1990).

Furthermore, Munday (2008: 44) argues that a translator operates in a social setting and interacts with 'publishers, editors, and agents' who generally have more power. Munday states that the translator who is appointed and remunerated by the target text publisher works on the discourse of the source text author. This discourse, which expresses the source text author's ideology, manifests itself in the author's "cognitive processes and linguistic choices" (Munday 2008: 44). In Munday's view, the translators also bring their own cognitive processes to the translation of the source text author's discourse.

Ideological translations mostly depend on the translators' identification with their target audience and changing the text accordingly (Al-Mohannadi 2008). Al-Mohannadi (2008) argues that if translator[s] know [their] target audience [they] may possibly be lured to modify the source text, even adding to or omitting from the original, to befit the standpoint of [their] readership. In Al-Mohannadi's (2008: 533) opinion, this is especially true with the translation of sensitive texts like religious ones or those expressing Marxist ideas, which "set out to advocate a particular way of life".

\section{Orwell's Animal Farm (1945)}

Animal Farm was published on the "heels of World War II" in Britain (Amirdabbaghian and Solimany 2013: 282). Orwell wrote Animal Farm as a commentary on the former Soviet Union situation. The exploitation of animals by human beings is similar to the exploitation of the proletariat by the rich, and Orwell incorporated Marx's theory from the animals' point of view. Orwell also included the Tehran Conference ${ }^{1}$ (1943) as an important incident in Animal Farm. Hosseini

${ }^{1}$ Tehran (or Teheran) Conference, was held during the World War II, from November 28 to December 1, 1943, in Tehran, Iran (Gellately 2013). It was a strategic meeting between the Big Three Allied Leaders, British Prime Minister Winston Churchill, U.S. President Franklin D. 
(2003: 158) noted that Orwell ended Animal Farm on a "loud note of discord" due to the Cold War as a result of the Tehran Conference between the USSR and the West.

Amirdabbaghian and Solimany (2013: 282) describe the novel as a fairytale where Orwell employs animal characters in order to "draw the reader away from the world of current events into a fantasy space where the reader can grasp ideas and principles more crisply". Animal Farm is Orwell's most significant investigation of political structures as Williams (1971: 70) states:

[It] is exclusive in his writing by the lack of his character. In this sense, it is a more comprehensive forecast of Orwell's method of observing the universe than whatsoever else he wrote.

Animal Farm (1945) differs from Orwell's previous novels both in its dissimilar prospect on ideology and the fictitious personality written in the third person narrative. This made it possible for Orwell to take his ideology a step forward and discover the influences and threats of dictatorial systems.

\section{Paratextual Materials}

Kovala (1996) states that paratext includes any meta-comment by the author, the translator, the editor, the illustrator, the publisher or a scholar. Genette (1997: 1) considers "author's name, a title, a preface, and illustrations" as a specific set of "verbal or other productions" which she calls paratext. For Genette (1997: xviii) paratexts are divided into two categories: (1) peritexts and (2) epitexts. Peritexts are physical supplemental materials surrounding the book. It can be either publisher's peritexts or introductions and/or prefaces of "the author, or the translator in the case of a translation, or [...] someone appropriate to present the text" (Neveu 2017: 28). Publisher's peritexts can include "front and back covers, spins, inside flaps, list of other works by the author or the translator, the title page, blurbs" (Genette 1997: xviii), etc. On the other hand, epitexts are external writings that are about the book, such as interviews and book reviews.

In order to create an impact on the reader, paratexts have provisional, spatial, pragmatic, functional and fundamental characteristics. The four basic functions that Genette (1997: 93) lists for paratexts are designating or identifying; description of the work (content and genre); connotative value; and temptation. Genette points out that "the meaning and function of paratexts are determined by the author and his/her allies, and that paratexts operate as a way of establishing and securing authorial intention" (Smith and Wilson 2011: 7-8). While Genette (1997) considers paratextual materials as additional elements to the body text, Gray (2015) states that paratext is a central, integral, important and constitutive part of the text. Therefore,

\footnotetext{
Roosevelt and the USSR Premier Joseph Stalin (Gellately 2013). The main discussion was about the opening of the second front in Western Europe, specifically — Nazi Germany (Gellately 2013). The failure of these Allies in making an agreement in the Tehran Conference was the chief reason for the Cold War (Hosseini 2003).
} 
paratexts principally control the reading experiences of the audience, mainly their interpretations and reactions.

On the other hand, Wolf (2006) categorizes paratexts into authorized: intracompositional, and unauthorized: extra-compositional. Authorized paratexts are shaping tools of the source text author while unauthorized paratexts are shaping tools added to the shaped source text by others including translator(s) (Wolf 2006). In fact, the study of paratexts in translation may also reveal clues to ideological and political agendas surrounding a published translation, as well as the role of the translator(s), editor(s) and/or publisher(s) in collaborating on these agendas.

Paratexts are more multipurpose and flexible than the main text, and accordingly, they function like "an instrument of adaptation" (Genette 1997: 408). In a translated text, the use of paratext "as a methodological tool has been supported as a way to define" (Pym 1997: 62-65) or to reflect the concept of the translation published by an agent (Tahir-Gürçağlar 2002) and to give information about the phenomena of translation (Kung 2013). Furthermore, Kovala (1996) believes in a wider look at paratexts mostly in relation to sociocultural contexts. The adaptable nature of paratextual materials and their connection to the process of translation encourages studies of different language exchanges. Studies of paratextual analysis include Koş (2009) of French-Turkish translation, Kung (2013) of TaiwanAmerican exchange, Pellat (2013) of Chinese-English texts, Núñez (2014) of English-Spanish paratext of La Independencia, Simón (2015) of Korean-English exchange, Hosseinzadeh (2015) of paratexts of Persian translations of fictions from different languages, Atefmehr (2016) of French/English-Persian paratexts of $19^{\text {th }}$ century Iran, Haslina (2017) of Malay-English renderings, Hijjo and Kaur (2017) of Arabic-English translation and Amirdabbaghian and Shunmugam (2019) of English-Persian paratexts during the 1979 Islamic Revolution in Iran, among others.

These studies are all considering the allographic (translatorial) paratexts while the current research is contrastive in nature and compares an authorial paratext (i.e. Orwell's Preface to a given edition of Animal Farm) with an allographic (translatorial) one (i.e. an Afterword written by a Persian translator of Orwell's text) in terms of ideology.

\section{Background of the Persian translators of Animal Farm}

Saleh Hosseini, born in 1946, translated Animal Farm into Persian in 2003. He graduated from George Washington University, USA, with a Ph.D. degree in English Literature (Islami 2003). He produced the literary translation of Orwell's Animal Farm (2003) while working as a full-time university professor of Languages and Linguistics at Shahid Chamran University of Ahvaz, Iran (Islami 2003). He presently serves as a retired professor of Linguistics at the same university. Hosseini was lauded as the leading critic and translator of the year, and the principal servant of publication in 1997 and 2003 by the Ministry of Culture and Islamic Guidance (see the portal of Shahid Chamran University of Ahvaz 2018). 
Hosseini does not profess allegiance to any specific political group or ideology, but he expresses the fact that Orwell fought politics with a touch of bitter sarcasm, and he believes that an important act in translation is to protect the language and especially literature against political destruction (Islami 2003; Seyyedi 2013).

Masoumeh Nabi Zadeh, whose name is mentioned on the book cover of the Persian translation of Animal Farm, is known to have "contributed in a few translations as an editor" in Doostan publication (Khorsand and Salmani 2014: 231). There was nothing else that could be found about her. As such, for this study, only Saleh Hosseini's beliefs are attributed to the 'Persian translation of Animal Farm'.

\section{Discussion of Paratexts of Animal Farm}

An afterword of a Persian translation of Animal Farm by Hosseini and Nabi Zadeh (2003) is analyzed here in comparison with the preface ${ }^{2}$ for Orwell's original text which was published by Prometej in Ukraine in 1947. There is no information about the original English preface by Orwell. According to Penguin's Appendix II on Animal Farm, the version which is known as Orwell's introduction for the Ukrainian translation of Animal Farm is a recasting back into English of the Ukrainian version.

In his preface, Orwell talks about his life first, to justify his political ideologies to his readers as he states that he would like to say something about himself and the experiences which had influenced his political position. Orwell was employed in the Burma Police, which was a most unsuited place for him as he had neither nationalistic sentiments for Burma nor supported the unjust imperialist activities of the British government which caused much suffering amongst the working class; the unsavory experience in the Burma Police made Orwell an anti-imperialist. This relates to van Dijk's (1998) belief that a profession one does can be one of the influencing factors in constructing a person's ideological knowledge. Orwell's deep concern for the plight of the working class made him a socialist. Orwell justifies his socialist ideas in the following words:

I became pro-Socialist more out of disgust with the way the poorer section of the industrial workers were oppressed and neglected than out of any theoretical admiration for a planned society (1947: Preface).

${ }^{2}$ This translation was intended for those Ukrainians in Germany who were living in the camps for displaced persons which were administrated by British and Americans after World War II. Ihor Szewczenko - [Igor Shevchenko], the person who was in charge of translation and distribution of Animal Farm among those Ukrainians and asked Orwell to write a specific preface for them, describes those people as supporters and defenders of the October Revolution who had turned against "the counterrevolutionary Bonapartism of Stalin" and the "Russian nationalistic exploitation of the Ukrainian people". They were common people, peasants, and laborers, few some-educated, but all were eager to read. Orwell insisted that he received no royalties for this edition, nor for other translations intended for those too poor to buy them, i.e. editions in Persian and Telugu. Orwell himself paid the production costs of a Russian-language edition printed on thin paper, which was intended for soldiers and others behind the Iron Curtain (This information is extracted from APPENDIX II of a version of Animal Fam which was published by Penguin in 2000). 
The false interpretation of the USSR socialist opinions in the European democratic countries made Orwell explore the mystery behind totalitarian propaganda by analyzing Marx's theory from the animals' view.

Hosseini (2003) in his Reflection on Animal Farm, called the novel an allegorical story. Like Orwell, Hosseini (2003) believes that Animal Farm aims to reveal the true face of the USSR. Hosseini (Hosseini and Nabi Zadeh 2003: 147) highlights "the unification of power and ideology and to eschew despotism" as the fundamental quests of a revolution in Orwell's point of view. Hosseini (2003: 146) also states that Orwell's intention in writing Animal Farm had deep implications; the translators cite a quote from Orwell about history as evidence that Orwell had wider targets and major themes such as the "incompatibility of justice and power, abuse of language, hence distortion of language directed on maintaining domination, extinction of history and the real world" (Hosseini and Nabi Zadeh 2003: 146):

Source Text:

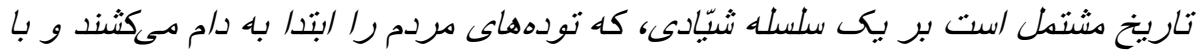

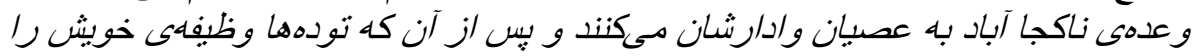

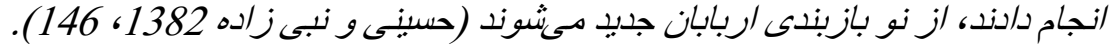

\section{Back Translation:}

history consists of a series of tricks that first, trap the masses and force them into a rebellion with the promise of a utopia, and once the masses did their duty, they would rebuild the new lords (Hosseini and Nabi Zadeh 2003: 146).

This interpretation of Orwell's intention by Hosseini (2003) reveals that language use is an important factor in influencing ideology.

As a sign of distortion of language, Hosseini (2003) includes an excerpt from Orwell's (1945) text, that is, "[A]fter the revolution, the cat joins the Re-education Committee and immediately learns to use the language in his own favor" (Hosseini and Nabi Zadeh 2003: 147). The excerpt describes the behavior of the cat, after the Rebellion, in this way:

Source Text:

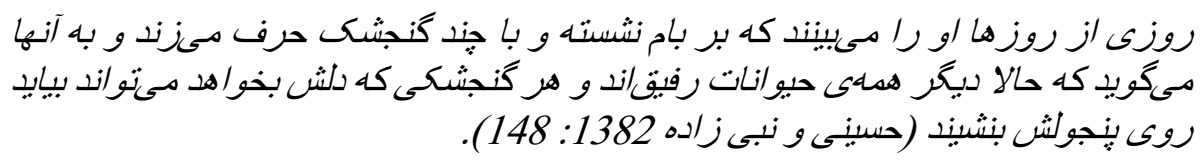

Back Translation:

She was seen a day sitting on a roof and talking to some sparrows who were just out of her reach. She was telling them that all animals were now comrades and that any sparrow who chose could come and perch on her paw (Orwell 1945: 14; Hosseini and Nabi Zadeh 2003: 148).

Language ideologies are defined as "the ideas with which participants and observers frame their understanding of linguistic varieties and map those 
understandings onto people, events, and activities that are significant to them" (Irvine and Gal 2000: 402). Irvine (1989: 249) describes linguistic ideologies as "the cultural system of ideas about social and linguistic relationships, together with their loading of moral and political interests". Likewise, Woolard and Schieffelin (1994: 57) state that language ideologies are not essentially about language; rather "they are in the service of other, more basic, ideological systems - concerning race, ethnicity, gender, sexuality, class, nationality, and other aspects of the social world - which they cloak in linguistic terms". Balockaite (2014: 42) indicates that "language is controlled through a variety of unstated rules and regulations" in a society that both "originate from social relations and also reflect them". Moreover, Balockaite (2014) believes in power relations between the speakers of different social groups as well as the state exposed to language ideologies.

Hosseini (2003: 147) also writes about the unification of power and ideology and eschews despotism as the fundamental quests of a revolution in Orwell's point of view. Hosseini (2003) tries to demonstrate Orwell's quest in his translation. In Persian translation of the song which Old Major [the old pig] taught others to sing, Hosseini (2003) manipulates the source text to show his hatred toward despotism.

Source Text:

Soon or late the day is coming, (Orwell 1945: 4)

Target Text:

$$
\text { ز زاغوت انسانها رها شويد (حسينى و نبى زاده 1382: 15) }
$$

Back Translation:

Get rid of the idolatrous humans! (Hosseini and Nabi Zadeh 2003: 15)

Here, the utterance ends in anger as there is an addition of " رها شويب [ræhp: كævi:d] (get rid)" as a verb at the end with the word " طاغوت [tw:yu:t] (idolatrous)" in the beginning. The whole sentence was changed as none of the words appear in the source text. This manipulation intensifies Orwell's message in the target language. While the source text sounds hopeful for the arrival of a day of freedom, Hosseini and Nabizadeh's (2003) translation is modulated to express a hostile feeling towards those who are curbing the freedom. It is noteworthy that the word " [tb:yu:t] (idolatrous)" became prevalent in the course of the Islamic Revolution and was mostly used to talk about the former monarchy regime (Yazdanimogaddam and Fakher 2011). As it is seen, idolatrous is associated with despotism as Hosseini believes that it has to be eschewed to fulfill the quests of a revolution and also confirms the aforementioned Munday's (2008) statement that the translators interpret the source author's discourse by their own cognition. Furthermore, Hosseini in this excerpt attempts to manipulate the original with addition and substitution to cater to the emotions of his readers as it is quoted earlier from Al-Mohannadi (2008). 
Hosseini (2003) sees the manipulation of the rules of the rebellion in Animal Farm as a distortion of language use and linguistic ideology which becomes one of the reasons for the animals' social corruptions and failed rebellion.

Source Text:

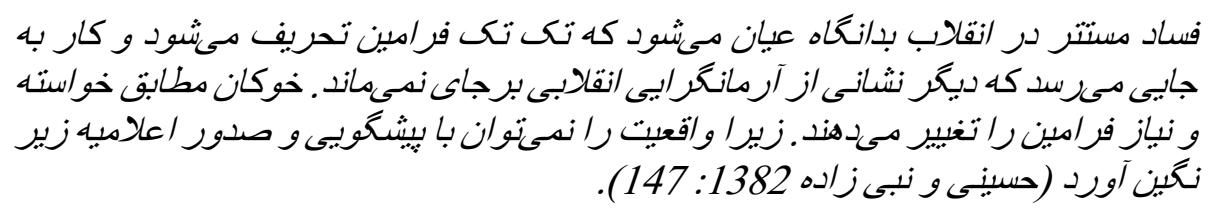

\section{Back Translation:}

[...] ulterior corruption in the revolution arises from the fact that every single decree is distorted and it goes so far that there is no trace of revolutionary idealism. The pigs change the orders for their own wills because they can't master the Reality by means of prediction and manifesto (Hosseini and Nabi Zadeh 2003: 147).

According to van Dijk (1998), ideology is defined as "the shared frameworks of social beliefs that organize and coordinate the social interpretations and practices of groups and their members" (van Dijk 1998: 8). Therefore, Hosseini (2003) sees that the state of "being deprived of the power of understanding and judgment" (as is the case of most of the animals at Manor Farm) serves as an advantage to the pigs to maintain power over the 'lesser' animals (Hosseini and Nabi Zadeh 2003: 148). But, the root of evil on the farm, in Hosseini's (2003: 148) opinion, is nothing but the disability of its inhabitants in determining the truth, and this point is depicted in the theme of language distortion. Hosseini (2003) proves the validity of his statement by citing examples from the text. First, the manipulation of the $6^{\text {th }}$ commandment is a reason to confuse the animals about the truth. Hosseini (2003) states that manipulating the $6^{\text {th }}$ commandment from "No animal shall kill any other animal" (Orwell 1945: 10) into "No animal shall kill any other animal without cause" (Orwell 1945: 37; Hosseini and Nabi Zadeh 2003: 148) shows the "transient nature of history" which is "one of the fears that the animals endure" (Hosseini and Nabi Zadeh 2003: 148).

The second example is the complicated financial and economic relationship of Napoleon with Frederick and Pilkington which "is fed to the animals through statistics, gross domestic product value, and the distribution of food" (Hosseini and Nabi Zadeh 2003: 149). Actually, it shows the use of language for a specific purpose. The third example which the translators provide for distortion of language is the manipulation of the sheep's slogan which changes from "Four legs good, two legs bad!" (Orwell 1945: 14) to "Four legs good, two legs better!" (Orwell 1945: 52; Hosseini and Nabi Zadeh 2003: 149). Hosseini (2003: 149) believes that "in the politically motivated world, the slogan is the impetus of history, and the slogan is a strategy". 
The next example is the manipulation of all the seven commandments by summarizing them into one commandment that is, "All animals are equal, but some animals are more equal than others" (Orwell 1945: 52-53; Hosseini and Nabi Zadeh 2003: 149) which shows the ongoing "abuse of language and the distortion of society" (Hosseini and Nabi Zadeh 2003: 149). The animals get confused and cannot judge between true and false because, on the one hand, they see the rules (i.e., the shared frameworks of social beliefs) as the pillars of their rebellion but then, on the other hand, and they also witness the manipulation of these 'sacred' rules and the pigs' convenient breaking of the rules for their own advantage (i.e. social interpretation and practice of beliefs of group members). This also, in Hosseini's (2003) opinion, leads to an oligarchy system of government in the Animal Farm society (Hosseini and Nabi Zadeh 2003: 150).

Lefevere (1992) refers to ideology as a translator's worldview and defines it as "the conceptual grid that consists of opinions and attitudes deemed acceptable in a certain society at a certain time, and through which readers and translators approach text" (as cited in Hermans 2014: 127). Therefore, it is noteworthy to highlight here that ideology in translation work is also tightly linked with politics and power dominance since Lefevere (1992) describes it as "the dominant concept of what society should be or can be allowed to be" (as cited in Shuping 2013: 57). Lefevere (1992) believes that translation is "productive for cultural studies and deserves to occupy a more central position in cultural history" (as cited in Shuping 2013: 59).

Hosseini's interpretation of Orwell's (1945) novel is thus, the translators' worldview in Iranian Post-Revolution society. The issues in Animal Farm are ideologically reflective of the Iranian political state under the Shah's rule that led to the Islamic Revolution. The rules and slogans of the 1979 Revolution are comparable to the seven commandments in the Animal Farm; the slogans during the Iranian Revolution which were concerned about social and welfare reformation (Panahi 2003) do not match the governors' actions since after the Revolution there have been several economic embezzlements in the 40 years of the Iranian Islamic Republic (Qasemi 2016) and Iranians social welfare has decreased in these three decades (Harris 2017).

\section{Conclusions}

The main purpose of this study is to prove that in literary translations, especially the Persian translation of Animal Farm, which in some cases may lead to transculturation, the role of the translator as the messenger in this crucial process can be leastwise as important as the message embedded in the literary work itself. Moreover, the dominant ideology in the target culture or the translator's own system of thought and philosophy can steer his pen on the paper and determine what to transmit from source culture to target culture and how to transmit it.

In this paper, the authorial paratext (the preface to Ukrainian translation of Animal Farm (1947) written by George Orwell) is contrasted to an allographic paratext (the Persian Afterword, i.e. Reflections on Animal Farm). The comparative 
analysis of the paratexts showed that Orwell and the Persian translator were of the same mind with regard to the false interpretation of the Soviet Union by the world at that time and this appears to be the main reason that had initiated their writing/translation of the novels. It is overlapped with Genette's (1997) proposed designating and identifying the function of the paratexts. The translators were acutely aware that the events in the fictional stories were, in fact, happening around them, which is what Genette (1997) regards as the connotative value in the paratexts functions. Lefevere (1992) believes in one's occupation as an aspect of patronage and one of the influencing factors in the translator's ideology. It, therefore, can be said that Hosseini (2003) as the post-Revolution Persian translator of Animal Farm, as well as a leading critic nominated by the Ministry of Culture and Islamic Guidance for a couple of years, was very likely influenced by his occupation as a critic to write a foreword to his translation which highlights language distortion in the animals' commandments and likewise in the promises made in the slogans chanted during the Islamic Revolution that insidiously led to a failed rebellion/revolution.

By comparing the novel's incidents with the real world, that is, by mentioning the misuse of language by the new leaders of the farm and the way they manipulate the slogans of the rebellion, it appears that Hosseini (2003) aims to criticize his own society after the Revolution since Iran, too, after nearly half a century, did not stand up to what was depicted in its Revolution slogans. To elaborate more on language misuse, Hosseini quotes some excerpts to justify what he believes and tries to evoke the readers' desire to go into the main text. This is compatible with the temptation function of paratexts expressed by Genette (1997).

In a broader context, Hosseini (2003) stresses avoiding despotism and he even demonstrates it in his translation to consider a revolution successful (as in the example quoted earlier). By comparing the novel's incidents with the real world, that is, by mentioning the misuse of language by the new leaders of the farm and how they manipulate the slogans of the rebellion, Hosseini (2003) may desire to criticize his own society after the Islamic Revolution since Iran, too, stood some distance from what had been illustrated in the revolutionary slogans and what it is now after nearly half a century. To conclude this article, it is noteworthy to say that "socially shared representations, as well as personal models, may influence the structures of discourse" (van Dijk 1998: 87) as it becomes obvious in this study.

(C) Amin Amirdabbaghian, Shangeetha R.K., 2020
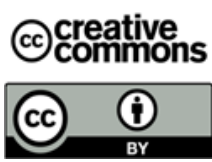

This work is licensed under a Creative Commons Attribution 4.0 International License https://creativecommons.org/licenses/by/4.0/ 


\section{REFERENCES}

Al-Mohannadi, S. 2008. Translation and ideology. Social Semiotics 18 (4). 529-542. doi: 10.1080/10350330802489050

Amirdabbaghian, A. 2019. Ideological Perspectives in the Persian Translations of Animal Farm and Nineteen Eighty-Four. Kuala Lumpur, Malaysia: University of Malaya Ph.D. Thesis.

Amirdabbaghian, A. \& Shunmugam. K. 2019. The Translator's Ideology: A Study of Three Persian Translations of George Orwell's Nineteen Eighty-Four. Lebende Sprachen: Zeitschrift für interlinguale und interkulturelle Kommunikation 64 (1). 1-22. doi:10.1515/les-2019-0001

Amirdabbaghian, A. \& Solimany, S. 2013. The Application of Baker's Taxonomy on Translation of Literary Texts A Case Study of George Orwell's Animal Farm. International Journal of Science and Research (IJSR) 2 (12). $280-284$.

Atefmehr, Z. 2016. Translator's Paratextual Visibility: the case of Iranian Translators from 1906 until 1926. inTRAlinea 18. 7-14. Retrieved from http://www.intralinea.org/ archive/article/2209

Balockaite, R. 2014. On Ideology, Language, and Identity: Language Politics in the Soviet and Post-Soviet Lithuania. Language Policy 13. 41-61. doi: 10.1007/s10993-013-9301-z

Bassnett, S, \& Lefevere, A. 1990. Translation, History and Culture. London and New York: Pinter.

Davison, P. 2002. The Complete Works of George Orwell (Vol. 19). London, UK: Secker \& Warburg.

Dimitriu, R. 2009. Translators' Prefaces as Documentary Sources for Translation Studies. Perspectives: Studies in Translatology 17 (3). 193-206. doi: 10.1080/ 09076760903255304

Faghih, E. \& Moghiti. R. 2017. Persian Renderings of English Conceptual Discourse Patterns: A Case Study of Animal Farm. International Journal of Comparative Literature \& Translation Studies 5 (3). 55 - 66. doi:10.7575/aiac.ijclts.v.5n.3p.55

Fairclough, N. 1992. Discourse and Social Change. Cambridge: Polity Press.

Gellately, R. 2013. Stalin's Curse: Battling for Communism in War and Cold War (Vol. 1st). Oxford, United Kingdom: Oxford University Press.

Genette, G. 1997. Paratexts: Thresholds of interpretation. (J. E. Lewin, Trans.) Cambridge: Cambridge University Press.

Gray, J. 2015. Afterword: studying media with and without paratexts. In L Geraghty (eds.), Popular Media Cultures, 230-237. London, UK: Palgrave Macmillan.

Harris, K. 2017. A Social Revolution: Politics and the Welfare State in Iran. Oakland: University of California Press.

Haslina Haroon. 2017. The translator's preface as a paratextual device in Malay-English literary translations. Translation \& Interpreting: The International Journal for Translation \& Interpreting Research 9 (2). 100-113. doi: 10.12807/ti.109202.2017.a07

Hatim, B, \& Mason, I. 1997. The Translator as Communicator. London \& New York: Routledge.

Hermans, T. 2014. Translation in Systems: Descriptive and System-oriented Approaches Explained. New York: Routledge.

Hijjo, N F. \& Kaur. S. 2017. The Paratextual Analysis of English Translations of Arabic Media Narratives on Daesh. 3L: The Southeast Asian Journal of English Language Studies 23 (3). 21 - 36. doi: 10.17576/3L-2017-2303-02

Hosseinzadeh, M. 2015. Translatorial Prefaces: A Narrative Analysis Model. International Journal of English Language, Literature and Translation Studies 2 (3). 311-319. 
Irvine, J. 1989. When Talk isn't Cheap: Language and Political Economy. American Ethnologist 16 (2). 248 -267.

Irvine, J. \& Gal. S. 2000. Language Ideology and Linguistic Differentiation. In P V Kroskrity (eds.), Regimes of Language: Ideologies, Polities, and Identities, 35-83. Santa Fe: School of American Research.

Islami, M. 2003. درباره ترجمه هاى 1984 [About 1984 Translations]. Haft. 12-13.

Khorsand, M. \& Salmani. B. 2014. Anthems as Propaganda: A Discoursal Translation Quality Assessment. International Journal of Language Learning and Applied Linguistics World (IJLLALW) 5 (3). 222-237.

Koş, A. 2009. Analysis of the Paratexts of Simone De Beauvoir's Works in Turkish. In A Pym \& A Perekrestenko (eds.), Translation Research Projects 1, 59-68. Tarragona: Intercultural Studies Group.

Kovala, U. 1996. Translations, Paratextual Mediation, and Ideological Closure. Target: International Journal of Translation Studies 8 (1). 119-147.

Kung, S W. 2013. Paratext, an Alternative in Boundary Crossing: A Complementary Approach to Translation Analysis. In V Pellat (eds.), Text, Extratext, Metatext and Paratext in Translation, 49-67. Newcastle: Cambridge Scholars.

Lefevere, A. 1985. Why Waste Our Time on Rewrites? The trouble with interpretation and the role of rewriting in an alternative paradigm. In T Hermans (eds.), The Manipulation of Literature: Studies in Literary Translation, 215-243. New York: Routledge.

Lefevere, A. 1992. Translation, Rewriting and the Manipulation of Literary Fame. London \& New York: Routledge.

Munday, J. 2008. Style and ideology in translation: Latin American writing in English. New York: Routledge.

Neveu, A. 2017. How Paratexts Influence the Reader's Experience of English Translations of La Fontaine's Fables. New Voices in Translation Studies (16). 23-54.

Núñez, G G. 2014. When a Translator Joins the Revolution: A Paratextual Analysis of Manuel García de Sena's La Independencia. TTR: Traduction, Terminologie, Rédaction 27 (1). 189-211. doi:10.7202/1037123ar

Orwell, G. 1945. Animal Farm. London: Secker and Warburg.

Orwell, G. 1947. Preface to translation of "Animal Farm: A Fairy Story". In G Orwell, Kolghosp Tvaryn (I. Szewczenko [Shevchenko], Trans., p. APPENDIX II). Germany: Prometej.

Orwell, G. 2003. Animal Farm. (S. Hosseini, \& M. Nabi Zadeh, Trans.) Tehran: Doostan Publication.

Panahi, M. 2003. جامعهشناسي شعار هاي انقلاب /سلامي /بران] [Sociology of Islamic Republic of Iran Slogans]. Tehran: Anidishe Moaser.

Pellatt, V. 2013. Packaging the Product: A Case Study of Verbal and Non-Verbal Paratext in Chinese-English Translation. JosTrans (20). 86-106.

Pym, A. 1997. Method in Translation History. Amsterdam: John Benjamins.

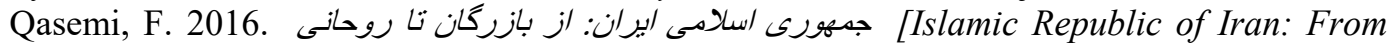
Bazargan to Rouhani]. New York: HandS Media.

Seyyedi, R. 2013. The Ideological Perspective towards Literary Translation: A Discourse Analysis of George Orwell's 1984 (the novel) and Its Three English into Persian Translations. Quchan, Razavi Khorasan, Iran: Islamic Azad University Master Dissertation.

Shuping, R. 2013. Translation as Rewriting. International Journal of Humanities and Social Science 3 (18). 55-59. 
Simón, E T. 2015. An evolution of Korean literary translation into English through its paratexts (1951-2000). Asia Pacific Translation and Intercultural Studies 224-234. doi:10.1080/23306343.2015.1100780

Smith, H, \& Wilson, L. 2011. Renaissance Paratexts. Cambridge: Cambridge University Press.

Tahir-Gürçağlar, Ş. 2002. What Texts Don't Tell, the Uses of Paratexts in Translation Research. In T Hermans (eds.), Crosscultural Transgressions: Research Models in Translation Studies II - Historical and Ideological Issues, 44-60. Manchester: St. Jerome.

Van Dijk, T A. 1998. Ideology: A multidisciplinary approach. New York: Sage.

Williams, R. 1971. George Orwell. New York: Columbia University Press.

Wolf, W. 2006. Introduction: Frames, Framings and Framing Borders in Literature and Other Media. In W Wolf \& W Bernhart (eds.), Framing borders in literature and other media, 1-40. New York: Rodopi.

Woolard, K A. \& Schieffelin. B B. 1994. Language Ideology. Annual Review of Anthropology 23. 55-82.

Yazdanimogaddam, M. \& Fakher. M. 2011. Examining the Effect of Ideology and Idiosyncrasy on Lexical Choices in Translation Studies within the CDA Framework. Journal of English Studies 1 (3) 27-36.

Zareh-Behtash, E. \& Chalabi. K. 2016. Ideology in Translation: The Impact of Socio-political Factors on Lexical Equivalents in Two Persian Translations of Animal Farm. Translation Journal 19 (2).

Shahid Chamran University, Ahvaz, Iran. n.d. دكتر صالح حسينى [Dr. Saleh Hosseini]. http://portal.scu.ac.ir/HomePage.aspx?TabID=4889\&Site=Lite.scu.ac\&Lang=fa-IR (accessed 06 February 2018).

\section{Article history:}

Received: 18 August 2019

Revised: 28 October 2019

Accepted: 19 November 2019

\section{История статьи:}

Дата поступления в редакцию: 18 августа 2019

Дата принятия к печати: 19 ноября 2019

\section{Bionotes:}

AMIN AMIRDABBAGHIAN, PhD, Researcher cum Translator (Persian/Turkic English), Curatorial Affairs Department, Islamic Arts Museum Malaysia, Kuala Lumpur, Malaysia. Research interests include cultural and ideological translation studies.

\section{Contact information:}

E-mail: amirdabbaghian@iamm.org.my

ORCID: https://orcid.org/0000-0001-6503-8446

SHANGEETHA R.K., PhD, Senior Lecturer, English Language Department, Faculty of Languages and Linguistics, University of Malaya, Kuala Lumpur, Malaysia. Research interests include diasporic writings and sociolinguistics aspects in literary texts.

\section{Contact information:}

E-mail: shangeetha@um.edu.my

ORCID: https://orcid.org/0000-0003-1320-7441 
Сведения об авторах:

АМИН АМИРДАББАГХЬЯН, научный сотрудник и переводчик (персидский / турецкий - английский) кураторского отдела Музея исламского искусства, Малайзия, Куала Лумпур. Научные интересы: культурологические и идеологические аспекты перевода.

Контактная информация:

E-mail: amirdabbaghian@iamm.org.my

ORCID: https://orcid.org/0000-0001-6503-8446

ШАНГИТА Р. К., доктор, доцент кафедры английского языка факультета языков и лингвистики Малайского университета, Куала Лумпур, Малайзия. Научные интересы: диаспорная литература и социолингвистические аспекты литературных текстов.

Контактная информация:

E-mail: shangeetha@um.edu.my

ORCID: https://orcid.org/0000-0003-1320-7441 